\title{
RELEVANSI ETIKA BISNIS DALAM HUKUM PERJANJIAN KREDIT PERBANKAN
}

\author{
Wulanmas APG. Frederik ${ }^{1}$
}

\begin{abstract}
Banking world is a business area that nowadays is conducted in a very tight competition; therefore, business people competing each other by paying attention to ethical norms in the more professional business climate will win. Business does not have the objective only to gain profits or profit oriented; however, it needs to consider human values. If not, it will sacrifice the lives of many people, thus, public have an interest to make business be conducted ethically. Legality and morality are connected to each other; however, it is different between one and another because an activity that is legally accepted is not always ethically accepted. Therefore, in any specific situation causing exclusion to profit oriented, it cannot be used as a basis to judge that there is no ethics in a banking credit agreement.
\end{abstract}

Keyword: ethics, banking, banking credit agreement

\begin{abstract}
Abstrak
Dunia perbankan pada saat ini adalah dunia yang sangat kompetitif, oleh karena itu pelaku bisnis dalam dunia perbankan saling bersaing dalam memberikan perhatian lebih terhadap etika untuk dapat memenangi persaingan dalam bisnis. Tujuan bisnis bukan hanya untuk mendapat keuntungan atau berorientasi keuntungan tetapi perlu mempertimbangkan nilai-nilai kemanusiaan. Jika hal ini tidak dilaksanakan maka akan banyak orang akan dikorbankan, maka publik mempunyai kepentingan agar bisnis ini dilakukan secara etis. Hukum dan moral saling berkaitan satu dengan yang lain, tetapi dua hal ini berbeda satu dengan yang lain karena dapat saja suatu kegiatan diterima secara hukum namun tidak dapat diterima secara etis. Dengan demikian maka dalam situasi yang khusus ketika orientasi keuntungan dikesampingkan, maka tidak dapat dijadikan dasar untuk menentukan bahwa tidak ada etika dalam perjanjian kredit perbankan.
\end{abstract}

Kata kunci: etika, perbankan, perjanjian kredit perbankan

${ }^{1}$ Penulis adalah Staf Pengajar Fakultas Hukum Universitas Sam Ratulangi, Manado. Alamat kontak: frederikapriesta@yahoo.com. 
mempertimbangkan nilai-nilai manusiawi, kalau tidak hal ini akan mengorbankan hidup banyak.

\section{Pembahasan}

\section{Nilai-Nilai Etika dalam Bisnis}

Bisnis adalah kegiatan ekonomis dan merupakan bagian yang penting dari masyarakat. Kegiatan bisnis berupa tukar-menukar, jual-beli, memproduksi-memasarkan pada dasarnya bertujuan untuk memperoleh keuntungan. Dipandang dari sudut ekonomis, good business atau bisnis yang baik adalah bisnis yang membawa banyak keuntungan. Akan tetapi perlu untuk diketahui bahwa dalam pencarian keuntungan dalam bisnis tidak bersifat sepihak sehingga bisnis berlangsung sebagai interaksi yang menguntung untuk kedua belah pihak yang melibatkan diri, maka suatu bisnis yang baik harus memenuhi standar etis. Hal ini berarti bahwa dalam berbisnis bisa tetap pada tujuannya yaitu mencari keuntungan akan tetapi diperlukan adanya nilai-nilai etika dalam berbisnis. ${ }^{2}$

Veronika Komalawati menyatakan bahwa Etika merupakan pedoman, patokan, ukuran untuk menilai perilaku manusia yang baik atau yang buruk yang berlaku secara umum dalam kehidupan bersama ${ }^{3}$

Selanjutnya menurut I. Gede A.B. Wiranata, bahwa Etika senantiasa terkait dengan konsumen ideal yang memuat tatanan etik dalam pergaulan yang melandasi tingkah laku untuk mewujudkan tata hubungan pergaulan manusia berdasarkan asas-asas baku, ideal dan penuh harmonisasi bila dilaksanakan. ${ }^{4}$

Sedangkan Magnis Suseno mengatakan etika adalah sebuah ilmu dan bukan sebuah ajaran, sedangkan "moralitas" adalah Petunjuk konkrit yang siap pakai tentang bagaimana kita harus hidup dan "etika" adalah perwujudan dan pengejawantahan secara kritis dan rasional ajaran moral yang siap kita pakai. ${ }^{5}$. Akan tetapi keduanya mempunyai fungsi yang sama yaitu memberi orientasi bagaimana dan bagaimana kita harus melangkah dalam hidup ini.

${ }^{2}$ Ruslan Rusado, "Seri Manajemen Public Relation; Aspek-aspek Hukum dan Etika dalam Kreatifitas Public Relation dan Kehumasan", (Jakarta: Ghalia Indonesia, 1995), hal. 37.

3 Veronika Komalawati, "Hukum dan Etika dalam Praktek Dokter", (Jakarta: Sinar Harapan, 1989), hal. 39.

${ }^{4}$ I Gede A.B. Wiranata, "Etika, Bisnis dan Hukum Bisnis (Sebuah Pemikiran Awal)", (Bandar Lampung: Universitas Lampung, 2007), hal. 7.

5 Franz M. Suseno, "Etika Dasar, Masalah-masalah Pokok Filsafat Moral", (Yogyakarta: tanpa penerbit 1987), hal. 14. 
Oleh karena pentingnya etika maka ada beberapa alasan untuk diketahui yaitu: ${ }^{6}$

1. Di dalam mengambil keputusan harus memperhatikan etika di mana etika menyangkut nilai-nilai luhur dalam bertindak dalam kehidupan seseorang dan menyangkut berbagai prinsip yang menjadi landasan bagi perwujudan nilai-nilai tersebut dalam semua bentuk dan jenis interaksi dan hubungan antara manusia;

2. Setiap bentuk kerja sama oleh sekelompok manusia didasarkan pada konvensi, kebiasaan dan kesepakatan bersama, sehingga penerapan etika dalam semua segi penghidupan dan pengalaman hidupnya perlu diperhatikan;

3. Etika dapat dijadikan sebagai pedoman berperilaku serta alat pengendali;

4. Etika menunjukkan nilai hakiki dari kehidupan manusia.

Perhatian etika untuk bisnis telah ada seiring dengan perkembangan bisnis itu sendiri, yaitu sejak bisnis lahir dalam rangka manusia memenuhi kebutuhan hidupnya, saat itu juga etikapun selalu mendampingi kegiatan bisnis.

Sering terjadi pertentangan pendapat bahwa etika dan bisnis merupakan dua hal yang berbeda serta terpisah satu sama lainnya, sehingga bisnis tidak dapat dinilai dari sudut pandang etika.

Pada dasarnya di dalam menjalankan kegiatan bisnis diperlukan etika, yakni: ${ }^{7}$

1. Bisnis tidak hanya bertujuan untuk profit melainkan perlu untuk mempertimbangkan nilai-nilai manusiawi, kalau tidak akan mengorbankan hidup banyak orang, sehingga masyarakat pun berkepentingan agar bisnis dilaksanakan secara etis;

2. Bisnis dilakukan di antara manusia yang satu dengan manusia yang lainnya, sehingga membutuhkan etika sebagai pedoman dan orientasi bagi keputusan, kegiatan dan tindak tanduk manusia dalam berhubungan bisnis satu dengan lainnya;

3. Bisnis saat ini dilakukan dalam persaingan yang sangat ketat, jadi orang bisnis yang bersaing dengan tetap memperhatikan normanorma etis pada iklim bisnis yang semakin professional justru akan menang;

4. Legalitas dan moralitas berkaitan, akan tetapi berbeda satu sama lain, karena suatu kegiatan yang diterima secara legal, belum tentu dapat diterima secara etis;

${ }^{6}$ A. Sonny Keraf, "Etika Bisnis (Membangun Citra Bisnis sebagai Profesi Luhur)", (Yogyakarta: tanpa penerbit, 1993), hal. 47-48.

${ }^{7}$ A. Sony Keraf, "Etika Bisnis, Tuntutan dan Relevansinya", (Yogyakarta: Kanisius, 1988), tanpa nomor hal. 
5. Etika harus dibedakan dari ilmu empris, yang berdasarkan pada suatu gejala atau fakta yang berulang terus-menerus dan terjadi di mana-mana akan melahirkan suatu hukum ilmiah yang berlaku universal;

6. Situasi khusus yang menyebabkan pengecualian terhadap etika tidak dapat dijadikan alasan untuk menilai bahwa bisnis tidak mengenal etika;

7. Aksi protes yang terjadi di mana-mana menunjukkan bahwa masih banyak orang serta kelompok masyarakat yang menghendaki agar bisnis dijalankan secara baik dan mengindahkan norma etika.

\section{Etika Perbankan dan Perjanjian Kredit Perbankan}

Pembahasan "etika perbankan" dimaksudkan untuk membahas kebiasaan yang baik atau peraturan-peraturan baik tertulis maupun tidak tertulis dalam dunia perbankan yang diterima dan ditaati baik oleh para bankir di Indonesia dan kemudian mengendap menjadi normatif dalam perilakunya. Etika perbankan di Indonesia haruslah sesuai dengan falsafah negara yang berlandaskan pada Pancasila. Sasaran etika perbankan dimaksudkan agar tercapai keserasian, kedamaian dan ketertiban dalam masyarakat perbankan.

Adapun jenis-jenis etika perbankan yang perlu mendapat perhatian di dalam Perjanjian Kredit, antara lain:

\section{a. Etika Di bidang Kepercayaan Masyarakat}

Salah satu kegiatan bank sebagai lembaga keuangan, adalah menyalurkan kredit bagi masyarakat yang membutuhkannya dan oleh bank dianggap layak untuk mendapatkannya.

Kelayakan dalam penyaluran kredit tidak terlepas dari prinsip 4C, yaitu:

a) Charakter;

b) Capacity;

c) Capital;

d) Collateral.

Masalah charakter berhubungan erat dengan kemauan untuk menepati kewajiban/janji terhadap bank, khususnya untuk membayar kembali suatu urang bersama bunganyatepat pada waktunya. Berbicara tentang kepercayaan masalah charakter yang kita tonjolkan. Walaupun capacity dan capital dimiliki oleh debitur, tetapi ia tidak berkemauan yang baik mengembalikan kreditnya berarti bank yang dirugian. Pengertian capacity berhubungan erat dengan kemampuan debitur mengelola pinjaman yang diberikan oleh bank. Pengertian capital berhubungan dengan soal keuangan dan 
permodalan si peminjam. Soal colleteral menyangkut jaminan yang merupakan pengaman terakhir dari kredit yang diberikan.

Setelah proses penilaian 4C telah dipenuhi oleh/debitur, maka yang menjadi permasalahan, bagaimanakah bank dapat menumbuhkan rasa percaya masyarakat pada umumnya atau debitur pada khususnya dalam kegiatan bank terhadap penyaluran kredit?

Bank sebagai pemberi jasa harus terpercaya. Program Bank dalam menyalurkan kredit benar-benar terpercaya tidak akan merugikan masyarakat pada umumnya atau/debitur pada khususnya.

Apabila etika perbankan dalam hal kepercayaan masyarakat dihubungkan dengan Perjanjian Kredit, maka setiap hal yang menjadi pokok dalam perjanjian haruslah jelas, misalnya:

a) Nilai kredit, bunga kredit, denda haruslah jelas, tepat dan terpercaya.

b) Setiap informasi yang diberikan oleh bank harus dapat dipercaya dan tidak boleh memberikan informasi yang mengandung kebohongan. Karena sudah menjadi ketentuan perbankan bahwa Bank harus dapat memberikan informasi yang jelas kepada debitur yang berkaitan dengan program pemberian kredit, sehingga resiko yang dialami oleh debitur dan bank dapat dihindari masyarakat ataupun nasabah/debitur bisa merasa aman dan percaya pada produk bank. ${ }^{8}$ Dengan demikian sudah menjadi kewajiban bank untu menyajikan informasi yang dapat dipercaya tentang hal yang berkaitan dengan penyelengaraan kredit yang disalurkan oleh bank guna menghindari kredit macet. Pemberian informasi ini harus dimulai dari awal perjanjian sampai pada penyelesaian kredit bahkan bank wajib memberi informasi berkaitan dengan resiko yang dapat timbul selama perjanjian kredit berlangsung. Hal ini dimaksudkan agar pada awal perjanjian, nasabah/debitur sudah mengetahui akan isi dan maksud dari perjanjian kredit tersebut. Apabila nasabah kurang pendidikan maka sudah merupakan servis bank untuk mendidik debitur ataupun memberikan nasihat demi untuk mencapai kepuasan nasabah/debitur dalam pelayanan bank ataupun menghindari kerugian yang akan dialami baik oleh bank maupun debitur akibat dari kurangnya pengetahuan dari debitur.

\section{b. Etika Perbankan di Bidang Menciptakan Itikad Baik}

Dalam rangka melaksanakan kepercayaan masyarakat, dengan sendirinya bank sebagai lembaga keuangan yaitu bankir Indonesia harus memenuhi berbagai syarat, yakni:

${ }^{8}$ Pranasari, K., Adrianus Meliala, "Praktek Pemberian Keterangan yang tidak Benar, Suatu Modus Penyimpangan Ekonomi", (Jakarta: UI Press, 1991), hal. 53. 
a) Bertakwa kepada Tuhan Yang Maha Esa;

b) Setia kepada Pancasila;

c) Berwibawa;

d) Jujur;

e) Cakap/ahli;

f) Adil.

Persyaratan tersebut di atas sebagai bagian dari moralitas yang harus dimiliki oleh bankir Indonesia di dalam lembaga keuangan. Moral ini merupakan suatu norma, etika sebagai tipe bankir ideal dalam masyarakat Indonesia, dengan demikian seorang bankir yang baik tidak akan melanggar etika perbankan ini.

Etika dan Moralitas tidak terlepas dengan itikad baik karena itikad baik merupakan moralitas dari para pihak dalam perjanjian, maka jika dihubungkan itikad baik dengan Perjanjian Kredit, maka segala hal yang ditetapkan sebagai klausul yang harus ditepati oleh kedua belah pihak, haruslah dibuat berdasarkan itikad baik. Janganlah oleh karena posisi bank yang lebih kuat sehingga bank mempunyai kekuasaan untuk membuat Perjanjian Kredit secara semena-mena demi keuntungan pihak bank semata tanpa memperhatikan kepentingan pihak debitur. orang khususnya debitur. Maka sudah selayaknyalah pihak bank harus mempunyai itikad baik dalam pembuatan klausul perjanjian, yang mewarnai keseimbangan hak dan kewajiban baik dari bank maupun dari nasabah/debitur. Janganlah yang nampak dalam klausul Perjanjian tersebut hanyalah Hak Bank dan Kewajiban Debitur sedangkan Hak Debitur dan Kewajiban Bank tidaklah nampak. Jika hal ini tidak nampak berarti jelaslah pihak bank tidak mempunyai itikad baik pada nasabah/debitur dan hanya mengejar keuntungan semata karena dalam etika Bisnis, pelaku usaha yaitu Bank tidak boleh hanya bertujuan untuk profit semata, melainkan perlu untuk mempertimbangkan nilai-nilai manusiawi, kalau tidak akan mengorbankan hidup banyak.

\section{c. Etika Perbankan Dalam Bidang Mencari Laba}

Yang dimaksud dengan mencari laba adalah kemampuan dari perbankan mencari laba. Laba sangat berpengaruh dalam tumbuh kembangnya usaha perbankan.

Salah satu usaha perbankan di dalam mencari laba, adalah menetapkan suku bunga guna pengembangan usaha perbankan itu sendiri. Bahkan seringkali penetapan suku bank bagi bank merupakan syarat mutlak yang tidak ada tawar-menawar lagi bahkan harus ditaati oleh debitur.

Bank dalam mencari laba secara etis penting sekali, karena sebagai berikut ${ }^{9}$ : 
a) Menambah kepercayaan para pemilik untuk menginvestasikan modalnya dengan membeli saham-saham yang dikeluarkan oleh bank, jika bank ingin memperbesar modalnya;

b) Bank yang terus menerus merugi tidak mungkin melanjutkan usahanya. Laba justru digunakan untuk memperbesar modal kerja;

c) Tidak seluruhnya laba dibagikan kepada pemilik saham, sebagian disisihkan dalam bentuk cadangan modal. Kenaikan cadangan modal menambah kredibilitas (tingkat kepercayaan) masyarakat terhadap bank;

d) Seandainya laba dianggap sangat kurang, maka besar kemungkinan modal bank tidak bertambah, bahkan pemegang saham dapat saja menjual sahamnya untuk diinvestasikan kepada perusahaan lain yang lebih menguntungkan;

e) Laba merupakan penilaian ketrampilan pemimpin bank;

f) (a). Menjauhi sikap pemerasan terhadap orang lain;

(b). Tidak melakukan perbuatan yang merugikan kepentingan umum.

\section{Peranan Hukum Dalam Penegakan Etika Perbankan}

Penerapan bahwa hukum merupakan satu sistem diuraikan sangat jelas, oleh Prof. Dr. Satjipto Rahardjo, S.H., dalam bukunya Ilmu Hukum, yaitu: ${ }^{10}$

Karena adanya ikatan asas - asas hukum itu, maka hukum pun merupakan satu sistem. Peraturan - peraturan hukum yang berdiri sendiri - sendiri itu lalu terikat dalam satu susunan kesatuan di sebabkan karena mereka itu bersumber pada satu induk penilaian etis tertentu. Teori Stufenbau dari Hans Kelsen dengan jelas sekali menunjukkan keadaan yang demikian itu. Kelsen mengatakan bahwa agar ilmu hukum itu benar - benar memenuhi persyaratan suatu ilmu, maka ia harus mempunyai objek yang bisa di telaah secara empirik dan dengan menggunakan analisis yang logis rasional. Untuk memenuhi persyaratan tersebut, maka tidak ada lain, kecuali menjadikan hukum positif sebagai objek studi. Yang di maksud dengan hukum positif disinilah adalah tatanan hukum mulai dari hukum dasar sampai kepada peraturan - peraturan yang konkret atau individual. Namun demikian, Kelsen juga mengatakan bahwa semua peraturan yang merupakan

9 O.P. Simorangkir, "Etika: Bisnis, Jabatan dan Perbankan", (Jakarta: Rineka Cipta, 2003), hal 164.

\footnotetext{
${ }^{10}$ Satjipto Rahardjo, "Ilmu Hukum", Cetakan kedua, (Bandung: Alumni, 1986), hal. 89.
} 
penilaian - penilaian etis. Semua peraturan yang ada harus bisa di kembalikan kepada nilai - nilai tersebut. Oleh karena Kelsen secara konsekuen menghendaki agar objek hukum itu bersifat empiris dan bisa di jelaskan secara logis, maka sumber tersebut di letakkannya di luar kajian hukum atau bersifat transeden terhadap hukum positif. Kajiannya bersifat meta yuridis. Justru dengan adanya satu susunan kesatuan dan dengan demikian pula merupakan satu sistem.

Selanjutnya pula, beliau dengan rujukan pada pendapatnya Dias menerangkan bahwa ada alasan lain untuk mempertanggung jawabkan, hukum itu merupakan satu sistem, yaitu:

Suatu sistem hukum itu bisa disebut demikian karena ia bukan sekadar merupakan kumpulan peraturan-peraturan belaka. Kaitan yang mempersatukannya sehingga tercipta pola kesatuan yang demikian itu adalah maslah keabsahannya. Peraturan-peraturan itu di terima sebagai sah apabila di keluarkan dari sumber atau sumber-sumber yang sama, seperti peraturan hukum, yurisprudensi dari kebiasaan. Sumbersumber yang demikian itu dengan sendirinya melibatkan kelembagaan, seperti pengadilan dan pembuat undangundang. Ikatan sistem itu tercipta pula melalui praktik penerapan peraturan-peraturan hukum itu. Praktik ini menjamin terciptanya susunan kesatuan dari peraturanperaturan tersebut dalam dimensi waktu. Sarana-sarana yang di pakai untuk menjalankan praktik itu, seperti penafsiran atau pola-pola penafsiran yang seragam menyebabkan terciptanya ikatan sistem tersebut.

Buku lainnya berjudul Hukum dan Masyarakat, Prof. Dr. Satjipto Rahardjo, S.H menguraikan bagaimana bekerjanya sistem hukum sebagai suatu proses, dengan merujuk pada pandapat dan uraiannya Lawrence M. Friedman dalam buku yang berjudul Legal Culture and Social Development. Dalam rangka memahami bekerjanya sistem hukum tersebut, maka uraiannya berpijak pada tiga komponennya, yaitu: ${ }^{11}$

Komponen yang bersifat struktural, adalah kelembagaan yang di ciptakan oleh sistem hukum itu dengan berbagai macam fungsinya dalam rangka mendukung bekerjanya sistem tersebut. Salah satu dari lembaga-lembaga semacam itu adalah pengadilan. Di dalam kerangka strukturalnya itu, maka kita, misalnya dapat membedakan antara jenis-jenis pengadilan yang di ciptakan oleh sistem hukum, seperti

11 Satjipto Rahardjo, "Hukum dan Masyarakat", Cetakan Pertama, (Bandung: Angkasa, 1986), hal. 84. 
pengadilan negeri, pengadilan administrasi, pengadilan agama dan sebagainya. Selanjutnya tentang ada atau tidaknya dasar-dasar peraturan yang melandasi bekerjanya lembaga hukum tersebut; tentang pembagian kompetensi di antara para hakim sendiri; tentang pembagian kekuasaan di antara hakim, legislator, eksekutif dan seterusnya. Secara singkat dapat di katakan bahwa dengan mengemukakan komponen strukturalnya ini di mungkinkan untuk meihat bagaimana sistem hukum itu memberikan pelayanan terhadap penggarapan bahan-bahan hukum secara teratur.

Komponen yang lain adalah yang bersifat kultural, terdiri dari nilai-nilai dan sikap-sikap yang merupakan pengikat sistem itu serta menentukan tempat sistem hukum itu di tengah-tengah kultur bangsa sebagai keseluruhan. Apabila kita melihat bekerjanya hukum sematamata dari komponen struktural, maka perhatian kita terutama hanya tertarik kepada jalannya atau bekerjanya sistem itu menurut prosedur sebagaimana telah di bagankan di dalam peraturan-peraturan hukum. Dengan masuknya pembicaraan mengenai komponen kultural hukum ini, maka nilai-nilai dan sikap-sikap sosial itu akan mengisi kekurangankekurangan yang di butuhkan untuk dapat menjelaskan penggunaan, ketidak-penggunaan, kesalah-penggunaan, dan pensalah-gunaan proses hukum serta sistem hukum. Dengan demikian, orang juga mengatakan bahwa kultur hukum itu berfungsi sebagai bensinnya motor keadilan. Apabila masalahnya di rumuskan ke dalam bentuk pertanyaanpertanyaan, maka pemahaman hukum dari sudut kulturnya ini mencoba untuk menjawab pertanyaan-pertanyaan, seperti:

a) Latihan, pendidikan, serta kebiasaan macam apakah yang di miliki oleh para sarjana hukum dan hakim ?

b) Bagaimanakah pikiran rakyat tentang hukumnya ?

c) Apakah perorangan atau golongan-golongan di dalam masyarakat itu datang ke pengadilan dengan senang hati ?

d) Untuk tujuan-tujuan apakah rakyat pergi ke ahli hukum dan untuk tujuan-tujuan apakah mereka memakai jasa pejabat-pejabat atau perantara-perantara lainnya?

e) Apakah yang di dalam masyarakat terdapat rasa hormat kepada hukum, pemerintah, tradisi?

f) Apakah hubungan antara struktur kelas di dalam masyarakat dengan soal penggunaan lembaga-lembaga hukum?

g) Sarana-sarana kontrol sosial informasi yang manakah yang dapat di jumpai di dalam masyarakat akan ganti sarana-sarana kontrol yang formal?

h) Siapa-siapakah di antara orang-orang atau golongan-golongan di dalam masyarakat yang lebih menyukai macam kontrol tertentu dan mengapa demikian? 
i) Apakah yang merupakan sumber legitimasi dari berbagai bagian dari sistem hukum itu?

Komponen yang ketiga disebut sebagai komponen substantif, adalah segi output sistem hukum. Kedalam pengertian ini dimasukkan norma-norma hukum itu sendiri, baik ia berupa peraturan-peraturan, doktrin-doktrin, keputusan-keputusan, sejauh semuanya ini digunakan, baik oleh pihak yang mengatur mapun yang di atur. Komponen substantif ini tidak terkait kepada formalitas tertentu, seperti apakah ia undangundang ataukah kebiasaan yang belum mendapatkan pengakuan secara formal. Yang di pentingkan adalah apakah ia di gunakan di dalamnya masyarakat."

Ketiga unsur hukum itulah yang menurut Lawrence M. Friedman, semuanya berada di dalam proses interaksi satu sama lain dan dengan demikian, membentuk totalitas yang di namakan sistem hukum. Konsep yang terpenting disini ialah kultur hukum, oleh karena ialah yang merupakan kunci untuk memahami perbedaan-perbedaan yang terdapat di antara sistem hukum yang satu dengan yang lain.unsur-unsur struktural serta substantif saja belum dapat menonjolkan karakteristik yang terdapat ada sistem hukum yang di pelajari, apalagi untuk memberikan jawaban tentang mengapa yang satu berbeda dengan yang lain. Seperti di katakan oleh Friedman: "Adalah unsur kultur hukum ini, yaitu seperangkat nilai-nilai dan sikap-sikap yang berkaitan dengan hukum, yang akan menentukan kapan dan mengapa dan di mana rakyat itu datang pada hukum atau pemerintah, atau pergi menghindar dari keduanya". 12

Dalam konteks hukum nasional, pendapat Friedman tersebut oleh Ahmad Ubbe, dalam uraiannya pada "Laporan Penelitian Pengembangan Budaya dan Hukum dalam Pembangunan Hukum Nasional', di tambahkan dengan unsur aparatur hukum, jadi sistem hukum nasional dengan substensinya meliputi substansi hukum, struktur hukum, kebudayaan hukum, dan aparatur hukum. Keempat komponen atau subsistem dari sistem hukum nasional itu, tidak hanya berkaitan satu sama lain, tetapi juga saling memengaruhi sehingga sekalipun kita berhasil menyusun materi hukum yang sempurna, tetapi hal tersebut tidak di dukung oleh kebudayaan hukum yang baik, maka seluruh komponen sistem hukum tidak mungkin dapat bekerja dengan baik. Hingga dengan demikian, materi hukum pun akan menjadi huruf mati. ${ }^{13}$

Uraian selanjutnya dengan tetap merujuk pada pendapatnya Friedman dan T. Gayus Lumbuun, di jelaskan bahwa:

${ }^{12}$ Ibid., hal. 86.

13 Ahmad Ubbe, Identitas Hukum Nasional Dalam Perspektif Reformasi Hukum, “Majalan Hukum Nasional", I (2004), hal. 11. 
Kebudayaan hukum dalam hal ini adalah sikap masyarakat terhadap hukum dan sistem hukum (people's atitude law and legal system), sedangkan sikap masyarakat dalam hukum sangat di pergaruhi oleh nilai-nilai budaya yang di anut oleh masyarakat, termasuk sistem kepercayaannya.

Berdasarkan pemikiran di atas, beliau menguraikan unsur-unsur pokok yang membentuk pengertian kebudayaan hukum (legal cultur), yaitu meliputi berbagai hal sebagai berikut:

a) Kebudayaan hukum adalah hasil dari perkembangan atau perbaikan melalui perbaikan atau aplikasi tertentu sehingga kualitasnya terus meningkat;

b) Dalam kebudayan hukum terdapat gagasan, keahlian, dan keterampilan yang di miliki oleh manusia yang di ahlikan, di komunikasikan, dan di turunkan dari generasi berikutnya;

c) Dalam kebudayaan hukum, ada proses belajar secara terus menerus menuju perbaikan-perbaikan;

d) Dalam perilaku sosial yang mencerminkan kebudayaan hukum setiap orang atau golongan penduduk memiliki ciri khasnya sendiri;

e) Kebudayaan hukum pada setiap kurun waktu tertentu selalu berubah-ubah.

Interaksi antara komponen atau fungsi yang ada dalam sistem hukum nasional akan mewujudkan "corak" atau "identitas" sistem hukum yang berbeda dari waktu ke waktu.

Prof. Dr. C. F. G Sunaryati Hartono, S. H., dalam bukunya Politik Hukum Menuju Satu Sistem Hukum Nasional, mengemukakan bahwa: ${ }^{14}$

Hukum mempunyai begitu banyak aspek dan terdiri dari jauh lebih banyak komponen atau unsur yang lain, seperti filsafat hukum, sumber hukum, kaidah hukum, yurisprudensi, hukum kebiasaan, penegakkan hukum, pelayanan hukum, profesi hukum, lembaga hukum, pranata hukum, prosedur dan mekanisme hukum, hukum acara, pendidikan hukum, perilaku hukum masyrakat maupun pejabat hukum, atau perilaku profesi hukum, kesadaran hukum, dan sebagainya. Semua itulah membangun sistem hukum, yaitu hubungan kaitan pengaruh mempengaruhi satu sama lain antara berbagai komponen atau unsur yang di sebut di atas tadi.

Buku lain Prof. Dr. C.F.G Sunaryati Hartono, S.H., mengemukakan: ${ }^{15}$

\footnotetext{
${ }^{14}$ Sunaryati Hartono, Op. Cit., hal. 38.

${ }^{15}$ Sunaryati Hartono, "Bhineka Tunggal Ika Sebagai Asas Hukum Bagi Pembangunan Hukum Nasional", Cetakan Pertama, (Bandung: PT Citra Aditya Bakti, 2006), hal. 45 - 47.
} 
"Jika hukum di lihat sebagai sistem, hukum terdiri dari unsur-unsur:

1. Nilai-nilai tentang kehidupan bermasyarakat;

2. Filsafat hukum;

3. Norma-norma hukum, yang terdiri dari:

a. Hukum Nasional:

1) Konstitusi;

2) Undang-undang;

3) Peraturan perundang-undangan yang lebih rendah dari undang-undang, seperti:

a) Peraturan Pemerintah,

b) Peraturan Daerah,

c) Peraturan Presiden,

d) Keputusan Presiden,

e) Dan Lain-lain.

4) Yurisprudensi Tetap (Putusan-putusan pengadilan yang di ikuti oleh hukum yang lebih rendah atau hakim yang memutus kemudian).

5) Hukum Kebiasaan:

a) Melalui kontrak-kontrak;

b) Dalam bidang/sektor bisnis tertentu;

6) Hukum Adat;

7) Hukum Agama

8) Dan Lain-lain

b. Hukum Internasional:

1) Perjanjian/konvensi multilateral yang telah di ratifikasi oleh pemerintah Republik Indonesia.

2) Perjanjian internasional bilateral antara Republik Indonesia dan negara asing

3) Hukum kebiasaan dan asas-asas hukum internasional yang berlaku universal.

4. Lembaga-lembaga hukum, seperti DPR, Lembaga eksekutif, peradilan, Lembaga pemerintah di pusat dan di daerah, Lembaga keamanan dan pertahanan negara, dan lain-lain;

5. Proses dan prosedur di lembaga-lembaga hukum;

6. Sumber daya manusia (mutu profesionalismenya, komitmen, dan moralnya);

7. Lembaga-lembaga pendidikan hukum dan sistem pendidikan hukum;

8. Sarana dan Prasarana (baik perangkat keras, perangkat lunak, dan brainwarenya, seperti kantor yang memadai; filling system dan perangkatnya; perabot, alat transportasi/ kendaraan, senjata atau komputer dengan seluruh perangkat dan sistemnya, dan sebagainya); 
9. Lembaga-lembaga pembangunan hukum, seperti Badan Pembinaan Hukum Nasional, Komisi Hukum Nasional, Badan Perencanaan Nasional, dan sebagainya;

10. Anggaran negara yang di sediakan untuk pemeliharaan dana pembangunan hukum.

Kesepuluh unsur sistem hukum itu saling berpengaruh dan bersinegi. Jika satu unsur saja tidak berjalan atau tidak mencukupi (misalnya kurangnya anggaran bagi sarana dan prasarana hukum, atau SDM yang tidak memadai, atau sistem pendidikan hukum yang sudah tidak memadai untuk abad ke-21, DPR yang tidak efektif, dan sebagainya) akan mengakibatkan macetnya seluruh sistem hukum".

Pendapat Prof. Dr. C.F.G Sunaryati Hartono, S.H., di atas, menguraikan ruang lingkup dan unsur - unsur yang membangun sistem hukum. Dalam rangka mengukur adanya sistem hukum, maka kita dapat berpedoman pada pendapatnya Fuller.

Fuller telah memberikan pendapatnya delapan asas yang dinamakannya Principles of legality, yaitu: ${ }^{16}$

a) Suatu sistem hukum harus mengandung peraturan - peraturan. Yang di maksud disini adalah bahwa tidak boleh mengandung sekadar keputusan - keputusan yang bersifat ad hoc.

b) Peraturan- peraturan yang telah di buat itu harus di umumkan

c) Tidak boleh ada peraturan yang berlaku surut, oleh karena apabila yang demikian itu tidak di tolak, peraturan itu tidak bisa di pakai untuk menjadi pedoman tingkah laku. Membolehkan pengaturan secara berlaku surut berarti merusak integritas peraturan yang di tujukan untuk berlaku bagi waktu yang akan datang.

d) Peraturan-peraturan harus di susun dalam rumusan yang bisa di mengerti.

e) Suatu sistem tidak boleh mengandung peraturan-peraturan yang bertentangan satu sama lain.

f) Peraturan-peraturan tidak boleh mengandung tuntutan yang melebihi apa yang dapat di lakukan.

g) Tidak boleh ada kebiasaan untuk sering mengubah-ubah peraturan sehingga menyebabkan seseorang akan kehilangan orientasi.

h) Harus ada kecocokan antara peraturan yang di undangkan dan pelaksanaannya sehari - hari.

Kedelapan asas yang di ajukannya itu sebetulnya lebih dari sekedar persyaratan dari adanya suatu sistem hukum, melainkan memberi pengkualifikasian terhadap sistem hukum sebagai sistem hukum yang

${ }^{16}$ Satjipto Rahardjo, Op. Cit., hal. $91-92$. 
mengandung suatu moralitas tertentu. Kegagalan untuk menciptakan sistem yang demikian itu tidak hanya melahirkan sistem hukum yang jelek, tetapi sesuai yang tidak bisa di sebut sebagai sistem hukum sama sekali.

Praktik kehidupan hukum, maka sistem hukum dan segala perwujudannya tumbuh dan berkembang bersama-sama dengan berbagai faktor non hukum yang ada di lingkungannya, seperti faktor ekonomi, politik, sosial, cultur, agama, dan sebagainya. Dalam lingkup kewilayahannya, sistem hukum mempunyai corak masing-masing yang tersendiri, yaitu sistem hukum nasional masing-masing negara. Sistem hukum nasional itu sendiri mempunyai ciri masing-masing pula. Adapun ciri tatanan hukum Indonesia, di sebutkan dalam buku Dasar-dasar Politik Hukum, karangan Iman Syaukani dan A. Ahsin Thohari, dengan merujuk pada pendapatnya Arief Sidharta, yaitu mengandung ciri: $^{17}$

(1). Berwawasan kebangsaan dan berwawasan nusantara

(2). Mampu mengakomodasi kesadaran hukum kelompok etnis kedaerahan dan keyakinan keagamaan

(3). Sejauh mungkin berbentuk tertulis dan terunifikasi

(4). Bersifat rasional yang mencakup rasionalitas efisien, rasionalitas kewajaran (redelijkheid), rasionalitas kaidah, dan rasionalitas nilai.

(5). Aturan prosedural yang menjamin transparansi, yang memungkinkan kajian rasional terhadap proses pengambilan putusan oleh pemerintah

(6). Responsif terhadap perkembangan aspirasi dan ekspektasi masyarakat.

Selanjutnya pula, Iman Syaukani dan A. Ahsin Thohari, menguraikan ada pendapat lain yang senada mengenai uraian ciri tatanan hukum nasional Indonesia tersebut, yakni hasil seminar tentang hukum nasional di Fakultas Hukum Universitas Islam Indonesia, yang setelah di bukukan berjudul Identitas Hukum Nasional, merekomendasikan bahwa hukum nasional yang sedang di bangun haruslah:

(1). Berlandaskan Pancasila, (filosofi) dan UUD 1945 (konstitusional).

(2). Berfungsi mengayomi, menciptakan ketertiban sosial, mendukung pelaksanaan pembangunan, dan mengamankan hasil-hasil pembangunan.

Perbankan merupakan suatu sistem karena telah memenuhi syarat sebuah sistem, yaitu suatu kesatuan yang bersifat kompleks, yang terdiri dari bagian-bagian yang berhubungan satu sama lain dan bagian-bagian tersebut bekerja sama secara aktif untuk mencapai tujuan pokok dari kesatuannya. Sistem perbankan Indonesia memiliki unsur-unsur:

${ }^{17}$ Iman Syaukani dan A. Ahsin Thohari, Op. Cit., hal. 70 -71. 


\section{Nilai-Nilai yang Hidup dalam Industri Perbankan}

Unsur nilai-nilai (moralitas) menjadi faktor penting dalam seluruh kegiatan perbankan sehingga hal ini di harapkan mendorong terciptanya etika usaha dan integritas yang tinggi dari seluruh stakeholders perbankan. Nilai-nilai mengesahkan eksistensi dan peranan sistem perbankan itu sendiri. Selanjutnya untuk agar senantiasa bisa memenuhi tuntutan-tuntutan perkembangan, nilainilai tersebut harus di segarkan dan di revitalisasi.

\section{Filsafat Perbankan}

Filsafat perbankan adalah pendalaman lebih lanjut menyangkut segala aspek mengenai perbankan. Perbankan dalam konteks tersebut, di jadikan sebagai objek pembahasan yang paling mendasar, yaitu meliputi konteks keberadaannya (ontologis) dan melihat pada konteks hakikatnya.

\section{Norma-Norma di Dunia perbankan}

Norma-norma di dunia perbankan yang terdiri dari norma yang berlaku secara nasional dan norma internasional, baik yang telah terkondifikasi secara tertulis dalam bentuk peraturan perundangundangan maupun yang masih berupa asas-asas hukum, serta kebiasaan-kebiasaan industri perbankan internasional yang berlaku universal (termasuk dalam norma yang tidak tertulis dalam bentuk peraturan perundang-undangan, yaitu fatwa-fatwa Majelis Ulama menyangkut perbankan syariah dan di mungkinkan pula yurisprudensi tetap).

\section{Lembaga-lembaga di Bidang Industri Perbankan}

Lembaga-lembaga di bidang Industri Perbankan seperti Bank Sentral, Lembaga Penjamin Simpanan, otoritas pengawas, dan sebagainya.

\section{Proses dan Prosedur di Lembaga-Lembaga Perbankan}

Proses dan Prosedur di Lembaga-Lembaga Perbankan seperti tata kelola perusahaan yang baik (good corporate governance) termasuk (operational governance) yang bersifat teknis, dan mikro yang menekankan kontrol pada praktik manajerialnya.

\section{Sumber Daya Manusia}

Sumber Daya Manusia (mutu profesionalismenya, komitmen, dan moralnya),

\section{Lembaga-Lembaga Pendidikan dan Sistem Pendidikan Perbankan}




\section{Sarana dan Prasarana (Baik Perangkat Keras, Perangkat Lunak, maupun Brainware-nya)}

Sarana dan prasarana (baik perangkat keras, perangkat lunak, maupun brainware-nya, seperti kantor yang memadai, filling system dan perangkatnya, perabot, alat transportasi/kendaraan, komputer dengan seluruh perangkat dan sistemnya, dan sebagainya).

\section{Kebijakan Pemerintah terhadap Industri Perbankan}

Kebijakan pemerintah terhadap industri perbankan (seperti diantaranya anggaran negara yang disediakan untuk pembangunan industri perbankan khususnya dan jasa keuangan pada umumnya).

Berdasarkan unsur-unsur yang di milikinya seperti di atas, maka sistem perbankan Indonesia mengandung komponen yang bersifat struktural, yaitu menyangkut kelembagaan yang di ciptakan dalam sistem perbankan tersebut dengan berbagai macam fungsinya untuk mendukung bekerjanya sistem tersebut: komponen yang lainnya, yaitu bersifat kultural, yang terdiri dari nilai-nilai dan sikap-sikap yang merupakan pengikat sistem itu serta menetukan tempat sistem perbankan itu di tengah-tengah kultur bangsa sebagai keseluruhan. Selain dua komponen di atas, juga tidak kalah pentingnya, yaitu komponen substansi, yang di antaranya, menyangkut proses dan prosedur di lembaga-lembaga perbankan yang bersangkutan, serta norma-norma hukum yang berkaitan dengan industtri perbankan itu sendiri, baik ia berupa peraturanperaturan, doktrin-doktrin, keputusan-keputusan, asas-asas, maupun prinsip perbankan, sejauh semuanya ini di gunakan, baik oleh pihak yang mengatur maupun yang diatur dalam menjalankan teknis operasional perbankan.

Unsur-unsur dari suatu sistem yang ada melakukan suatu proses interaksi satu sama lain, dengan demikian membentuk totalitas yang dinamakan sistem perbankan. Secara sederhana, sebuah sistem dapat di lacak melalui fungsinya. Sistem yang baik adalah jika ia dapat menjamin keberlangsungan proses interaksi yang berkelanjutan antara input, proses, dan output yang di hasilkan. Dalam konteks sedemikian itu, salah satu tugas awal dari sebuah sistem perbankan adalah melancarkan pemindahan dana dari suatu institusi/mereka yang berlebihan dana ke institusi atau perusahaan yang memerlukannya atau sebaliknya. Perpindahan dana jika berjalan efektif dan efisien, akan mempunyai manfaat khususnya bagi masyarakat dan umumnya untuk perekonomian negara.

Bentuknya sebagai sistem, maka di tuntut tetap harus responsif terhadap perkembangan aspirasi dan harapan masyarakat pada sistem tersebut. Hal demikian di dasari dan harapan masyarakat pada sistem tersebut. Hal demikian di dasari karena suatu sistem perbankan itu bisa di sebut demikian karena ia bukan sekadar merupakan kumpulan operassional perbankan belaka, melainkan totalitas dalam kerangka yang menyeluruh serta memiliki pula keterkaitannya secara fungsional, baik 
antara unsur-unsurnya di dalam sistem perbankan tersebut maupun antara perbankan dengan sistem yang terkait secara menyeluruh, termasuk kelembagaan infrastruktur yang menunjangnya.

Etika pada umumnya didefinisikan sebagai suatu usaha yang sistematis dengan menggunakan rasio untuk menafsirkan pengalaman moral individual dan sosial sehingga dapat menetapkan aturan untuk mengendalikan perilaku manusia serta nilai-nilai yang berbobot untuk dapat dijadikan sasaran dalam hidup. ${ }^{18}$

Usaha ini tujuannya untuk memantapkan serta meyakinkan orang akan ketentuan-ketentuan/aturan-aturan, dan nilai-nilai yang patut dianut dan dikejar. ${ }^{19}$

Nilai-nilai moral atau nilai-nilai etika diatur dalam Pasal 1337, 1338 Ayat (3) KUH Perdata dan Pasal 1339 KUH Perdata.

Pasal 1337 KUH Perdata, menyatakan:

Suatu sebab adalah terlarang, apabila dilarang oleh undangundang, atau apabila berlawanan dengan kesusilaan baik atau ketertiban umum.

Ketentuan tersebut di atas menjelaskan suatu perjanjian akan dapat dibatalkan jika bertentangan dengan Undang-undang, kesusilaan yang baik dan atau ketertiban umum. Hal ini berarti suatu klausula dalam perjanjian kredit akan batal jika bertentangan dengan kesusilaan dan ketertiban umum

Pengembangan terhadap pengertian kesusilaan yang baik, terlebih lagi bagi pengertian ketertiban umum adalah merupakan jalan terbaik untuk diterapkan mengatasi masalah yang bisa terjadi sehubungan dengan berkembangnya penggunaan syarat-syarat umum dalam berbagai perjanjian-perjanjian.

Pasal 1338 Ayat (3) KUH Perdata, menyatakan: "Suatu Perjanjian harus dilaksanakan dengan itikad baik".

Rumusan ini memberikan arti kepada kita semua bahwa suatu perjanjian yang dibuat hendaknya tidak merugikan kepentingan para pihak yang terikat dalam perjanjian, yaitu: debitur ataupun kreditur.

Pasal 1339 KUH Perdata, menyatakan:

Suatu Perjanjian tidak hanya mengikat untuk hal-hal yang dengan tegas dinyatakan di dalamnya, tetapi juga untuk segala sesuatu yang menurut sifat perjanjian, diharuskan oleh kepatutan, kebiasaan atau undang-undang.

${ }^{18}$ F. Magnis-Suseno, "Kuasa dan Moral", (Jakarta: Gramedia, 1986), tanpa nomor hal.

19 Tjahjadi S.P., "Hukum Moral; Ajaran Immanuel Kant tentang Etika dan Imperatif Kategoris", (Yogyakarta: Kanisius, 1991), hal. 97. 
Asas kepatutan diatur dalam Pasal 1339 KUH Perdata, di mana pengertian "kepatutan" sama dengan "itikad baik". Dengan kepatutan dari Pasal 1339 tidak banyak mempunyai arti lain daripada itikad baik yang terdapat dalam pasal 1338 Ayat (3), hanya saja pengertian itikad baik lebih menunjukan suatu ujud daripada kata abstrak kepatutan. ${ }^{20}$

Hal ini berarti pasal 1338 ayat 3 KUH Perdata senafas dengan pasal 1339 yang menyatakan bahwa suatu perjanjian tidak memenuhi syaratsyarat itikad baik dan kepatutan/kepantasan menjadi batal dan tidak mengikat. Sebab suatu perjanjian selain menghendaki adanya syarat itikad baik juga syarat kepatutan yang harus ditaati oleh para pihak yang terikat dalam perjanjian tersebut.

Itikad baik dan kepatutan sebagaimana yang diatur dalam KUH Perdata Pasal 1338 Ayat (3) dan Pasal 1339, merupakan "etika" dan standart "moral" dalam berbisnis. Sebab etika adalah refleksi kritis terhadap moralitas, dimana etika bermaksud menghimbau orang untuk bertindak sesuai dengan moralitas, dan etika bermaksud untuk menggugah kesadaran manusia untuk bertindak secara bebas dan dapat dipertanggung-jawabkan. Sebab asas itikad baik dengan asas kesusilaan, yang mempersoalkan keadaan-keadaan sebagai berikut:

(1). Sampai dimana kelakuan si pengusaha dinyatakan sebagai kesalahan.

(2). Bagaimana sifat dan isi syarat-syarat perjanjian itu.

(3). Bagaimana kedudukan para pihak dalam hubungan pembuatan perjanjian Kredit.

(4). Sampai di mana pihak lawan (nasabah) sadar akan makna syaratsyarat tersebut.

Pada dasarnya Etika dan Moralitas telah dianut dalam Asas-asas Hukum Perdata yakni: Asas Moral dan Asas Kepatutan.

Adapun yang dimaksud dengan Asas Moral tersebut, adalah: menghendaki para pihak yang terikat dalam perjanjian mempunyai motivasi untuk melakukan perbuatan hukum berdasarkan kesusilaan (moral), sebagai panggilan dari hati nuraninya.

Standart moral di dalam berbisnis sebagaimana yang dikemukakan di atas ternyata kurang diperhatikan oleh para pelaku bisnis dalam menjalankan kegiatan bisnis perbankan khususnya di dalam hubungan perjanjian kredit. Seringkali nasabah perbankan dijadikan sebagai objek dalam bisnis dan bukan sebagai subjek di dalam bisnis, sehingga/debitur tidak diberi kesempatan untuk duduk bersama di dalam pembuatan perjanjian standar perbankan yang termuat dalam perjanjian kredit perbankan di dalam mengutarakan keinginan dan haknya sebagai subjek hukum.

${ }^{20}$ Pitlo, "Evolutie in het Privaatrcht", HD, Loc. cit , hal. 59-61. 
Selanjutnya maksud dari Asas Kepatutan, adalah bahwa "kepatutan" tidak berbeda dengan "itikad baik". Hal ini berarti "kepatutan" dari pasal 1339 tidak banyak mempunyai arti lain daripada "itikad baik" yang terdapat dalam pasal 1338 ayat 3, hanya saja pengertian itikad baik lebih menunjukan suatu ujud daripada kata abstrak kepatutan.

Adapun maksud dari "kepatutan (billijkheid)" dan "itikad baik (geode trouw)" adalah suatu perbuatan sesuai dengan bonafides berarti berbuat berdasar pengertian yang baik, jujur dan lurus, hal ini terdapat dalam jiwa manusia.

Unsur itikad baik/kepatutan dapat dimasukkan sebagai pelengkap oleh hakim dalam menemukan hukum demi untuk memenuhi rasa keadilan dari para pihak yang terikat dalam suatu perjanjian.

Hal ini disebabkan bahwa fakta menunjukkan bahwa secara bertahap dan pasti, bentuk-bentuk kontrak yang digunakan di dalam masyarakat telah mengalami perubahan dan perkembangan. Semula kontrak dipahami sebagai ketentuan dan persyaratan yang disepakati para pihak sebagai hasil perundingan atau negoisasi antar para pihak yang membuatnya, namun pada akhirnya ditemukan dalam standart kontrak tidak dirasakan adanya rasa keadilan dan persamaan kedudukan di dalam hukum. Hal ini disebabkan kontrak baku dirancang, dibuat ditetapkan, digandakan serta disebarluaskan secara sepihak oleh satu pihak yaitu Bank, sedangkan pihak lain yaitu nasabah/debitur hanya dapat menerima atau menolak (take it or leave it).

Mengacu pada asas kepatutan dan itikad baik niscaya Bank dapat menjalankan usaha perbankan dengan bertitik tolak pada asas kepatutan dan itikad baik.

Maka demi mewujudkan perlindungan hukum bagi debitur di dalam perjanjian kredit perbankan perlu adanya sistem pengawasan terhadap pembuatannya.

\section{Penutup}

Kegiatan bisnis tidak hanya bertujuan untuk memperoleh laba guna kepentingan bank itu sendiri melainkan perlu untuk mempertimbangkan nilainilai manusiawi, sebab jika tidak akan mengorbankan hidup banyak orang, termasuk masyarakat pada umumnya dan/debitur pada khususnya. Untuk itu etika tersebut di atas dapat dijadikan sebagai pedoman berperilaku serta alat pengendali.

Maka bank di dalam penetapan suku bunga haruslah memperhatikan etika perbankan dalam bidang mencari laba, dengan tidak hanya memperhatikan keuntungan semata secara sepihak yaitu bagi pihak bank akan tetapi juga harus memperhatikan suatu perbuatan yang tidak akan merugikan pihak yang lain yaitu pihak nasabah/debitur. Kenaikan suku bank secara tibatiba tanpa pemberitahuan kepada nasabah/debitur jelaslah sudah menyalahi etika perbankan di bidang mencari laba dan etika perbankan dalam bidang itikad baik. 


\section{Daftar Pustaka}

Hartono, Sunaryati C.F.G. Bhineka Tunggal Ika Sebagai Asas Hukum Bagi Pembangunan Hukum Nasional, Cetakan Pertama, Bandung: PT Citra Aditya Bakti, 2006

Keraf, Sonny A. Etika Bisnis (Membangun Citra Bisnis sebagai Profesi Luhur), Yogyakarta: tanpa penerbit,1993.

- Etika Bisnis, Tuntutan dan Relevansinya, Yogyakarta: Kanisius, 1998.

Komalawati Veronika, Hukum dan Etika dalam Praktek Dokter, Jakarta: Sinar Harapan, 1989.

Magnis-Suseno, F. Kuasa dan Moral, Jakarta: Gramedia, 1986.

. Etika Dasar, Masalah-masalah Pokok Filsafat Moral, Yogyakarta: tanpa penerbit, 1987.

Pranasari, K., dan Adrianus Meliala. Praktek Pemberian Keterangan yang tidak Benar, Suatu Modus Penyimpangan Ekonomi, Jakarta: UI Press, 1991.

Rahardjo, Satjipto. Ilmu Hukum, Cetakan kedua, Bandung: Alumni, 1986.

. Hukum dan Masyarakat, Cetakan Pertama, Bandung: Angkasa, 1986.

Ruslan, Rusado. Seri Manajemen Public Relation: Aspek-aspek Hukum dan Etika dalam Kreatifitas Public Relation dan Kehumasan, Jakarta: Ghalia Indonesia, 1995.

Simorangkir, O.P. Etika: Bisnis, Jabatan dan Perbankan, Jakarta: Rineka Cipta, 2003.

Tjahjadi S.P. Hukum Moral; Ajaran Immanuel Kant tentang Etika dan Imperatif Kategoris, Yogyakarta: Kanisius, 1991.

Ubbe, Ahmad. "Identitas Hukum Nasional Dalam Perspektif Reformasi Hukum", Majalah Hukum Nasional I, 2004: 11.

Wiranata, I Gede A.B. Etika, Bisnis dan Hukum Bisnis (Sebuah Pemikiran Awal), Bandar Lampung: Universitas Lampung, 2007. 